Наталія Лісневська

Глухівській національний педагогічний університет імені Олександра Довженка ORCID ID 0000-0001-7910-7932

DOI 10.24139/2312-5993/2020.01/073-082

\title{
ОСОБЛИВОСТІ ЗАСТОСУВАННЯ КОЛЬОРОТЕРАПІЇ В РОБОТІ 3 ДІТЬМИ ДОШКІЛЬНОГО ВІКУ ЯК ЗАСОБУ ВПЛИВУ НА ЇХ ЗДОРОВ'Я
}

У статті подається історичний огляд досліджень минулого й сьогодення щодо впливу кольору на організм людини з лікувальною метою. Розкривається значення кольоротерапії як нетрадиційного засобу збереження та змічнення здоров'я дітей дошкільного віку. Дається характеристика кожного кольору з точки зору впливу його на організм людини. Називаються методи застосування кольоротерапії в роботі з дітьми дошкільного віку в умовах закладу дошкільної освіти та описуються шляхи їх реалізації. Подаються приклади діагностичних, графічних і реабілітачійних вправ. Визначається вплив кольоротерапії на збереження здоров'я дітей-дошкільнників і перспективи подальших досліджень особливостей застосування кольоротерапії в дидактичних іграх і в арт-терапії.

Ключові слова: колір, кольоротерапія, оздоровчі технології, нетрадиційні засоби оздоровлення, кольорова вода, кольорові ванни, діагностична вправа, реабілітаційна вправа.

Постановка проблеми. Здоров'я - це найцінніше, що є в людини. Тому від народження дітей варто вчити зберігати та зміцнювати здоров'я, виховувати в них ціннісне ставлення до нього. Відомо, що ефективними засобами покращення здоров'я $€$ традиційні, однак педагогами велике значення також надається й нетрадиційним засобам оздоровлення оздоровчим технологіям. Серед розмаїття оздоровчих технологій (аромотерапія, фітотерапія, музикотерапія тощо), що широко застосовуються в оздоровчій роботі з дошкільниками, на жаль, мало уваги преділяється такій технології як кольоротерапія.

Аналіз актуальних досліджень. Історичні дані свідчать про те, що вплив кольору на організм людини вивчається вже понад 5 тис. років, починаючи зі Стародавнього Египту та Давнього Риму, Китаю, Індії, а пізніше Середньовіччя. Ще Авіценна радив для покращення здоров'я використовувати ванни забарвлюючи воду різним кольором. Пізніше відомий німецький письменник і філософ Й. Гете вивчав особливості впливу різних кольорів на фізіологічний і психічний стан людини, що відображено в книзі «Вчення про колір» (Goethe, 2012; Izotova, Sarafanova, M ithyo, Ionova, 2007).

Одним із перших учених, який розкрив роль сонячного та блакитного світла був А. Плезантон. Свої думки він виклав у книзі «Блакитне та сонячне світло» (Augustus). Pleasanton, «Blue and Sun-Lights»). 
Саме він уперше почав лікувати хронічні захворювання людей за допомогою блакитного світла. у 1877 р. лікар С. Пенкост, автор книги «Блакитне та червоне світло» (Seth Pancoast, «Blue and Red Lights»), помітив, що фіолетове світло вбиває більшість небезпечних бактерій і заспокоює нервову систему. В Англії в цьому самому році вченими Дж. Дауном і Р.Блунтом були відкриті лікувальні властивості ультрафіолетових променів у лікуванні шкіряних захворювань і рахіту (Изотова, Сарафанова, Мицьо, Ионова, 2007, с. 192).

Проте справжньою сенсацією стала книга лікаря Е. Беббіта «Принципи світла та кольору» (Edwin Babbitt, «The Principles of Light and Color»). Учений почав застосовувати лікування світлом, пропущеним через кольорові фільтри, причому промені направляли на різні частини тіла хворої людини. Датський фізіотерапевт Н. Фінсен досліджував вплив концентрованого сонячного світла на захворювання шкіри, за що в 1903 році отримав Нобелівську премію. Пізніше російський учений і лікар В. Бехтерєв також почав займатися вивченням питання про взаємодію органів людського тіла й колірних променів, що було відображено в праці «Світлотерапія в лікуванні нервових хвороб». У 90-х рр. XIX ст. було з'ясовано, що ультрафіолетові промені здатні знищувати багато хвороботворчих бактерій. Після цього ультрафіолет почали застосовувати в лікарнях для дезінфекції приміщень і лікування хворих із ранами, опіками та застудними захворюваннями, що продовжується й донині (Izotova, Sarafanova, M ithyo, Ionova, 2007; Skrypnyk, 2014).

Наразі проблема впливу кольоротерапії на здоров'я досить актуальна, яку можна використовувати по-різному: як засіб корекції різних форм порушення зору (Герасименко, 2014, с. 20); у вигляді зосередження зору на предметах різного кольору, спостереження за квітами в куточку природи (Денисенко, 2006, с. 17); в оформленні інтер'єру групових кімнат, віталень, фізкультурної зали та кабінету ЛФК закладів дошкільної освіти (Denysenko, 2006; Yefimenko, 1998).

Мета дослідження - розкрити значення кольоротерапії та визначити методи її застосування для збереження та зміцнення здоров'я дітей дошкільного віку, дати їм характеристику.

Виклад основного матеріалу. Колір оточує нас протягом усього життя та впливає на організм людини, її психіку й нервову систему. Людина здатна розрізняти близько 6 млн відтінків кольорів (Скрипник, 2014, с. 15).

Кольоротерапія - це лікування організму людини за допомогою кольору. Доведено, що в бідному на кольори середовищі виникають симптоми асенізації та навіть затримка інтелектуального розвитку в дітей. Варто відмітити, що кольоротерапія, сприяє не тільки зміцненню та покращенню здоров'я дошкільників, а також, у загальних рисах, їх ефективному руховому розвитку, формуванню особистості, покращенню 
психічних функцій, настрою, самопочуттю, зняттю стресу, створенню позитивного мікроклімату в групі. Однак, для успішного використання кольоротерапії в закладах дошкільної освіти все ж таки необхідно знати, як діє той чи інший колір на організм людини.

Загальновідомо, що всі кольори поділяються на дві групи: хроматичні, які, у свою чергу, поділяються на кольори теплі (спектральні) жовтий, помаранчевий, червоний, рожевий, світлі відтінки зеленого й коричневого та холодні (спектральні) - зелений, блакитний, синій, фіолетовий; - ахроматичні - сірий, білий, чорний. Неспектральним $\epsilon$ коричневий колір - суміш теплих і холодних відтінків. Так (Izotova, Sarafanova, Mithyo, Ionova, 2007; Kiseleva, 2006; Skrypnyk, 2014), жовтий допомагає уникнути депресії, покращує настрій, самопочуття, зір, пам'ять, розумові здібності, підвищує концентрацію уваги, активність рухових центрів, має послаблюючий і жовчогіний ефект, сприяє очищенню шкіри, печінки та кишківника, знімає нервове напруження, розвиває комунікабельність і товариськість, дає натхнення, оновлює цілющі сили організму. Не варто застосовувати при підвищеній температурі тіла, невралгії, перезбудженні нервової системи. Помаранчевий- покращує настрій, апетит, роботу селезінки, шлунково-кишкового тракту та нирок, зміцнює імунітет, сприяє пізнавальній активності, розвитку інтелектуальних можливостей, мобілізує сили організму й тонізує його, дає відчуття тепла й затишку, стимулює комунікабельність і товарискість. У надлишку призводить до підвищеного збудження, подразнення нервової системи. Червоний- стимулює роботу головного мозку, підвищує енергійність, кров'яний тиск, прискорює серцебиття, обмін речовин, покращує імунітет, збільшує частоту дихання, допомагає при втомі, стресі та виснаженні, сприяє появі віри в себе й високій самооцінці. У великій кількості призводить до перезбудження, втоми, розоратувань, агресії, появи головного болю, погіршення психологічного клімату. Рожевий- сприяє розслабленню, зняттю зовнішніх і внутрішніх психологічних затискачів, знижує агресивність і збудливість нервової системи.

Зелений- заспокоює нерви, відновлює нервову систему, запобігає втомі та роздратуванню, знімає головний біль, напругу та втому очей, знижує кров'яний тиск, розширює судини, підвищує їх тонус, сприяє регенерації та зрощенню зламаних кісток, допомагає розслабитись і при безсонні. Блакитний- має незначний заспокійливий, снодійний і антисептичний ефект, допомагає зібратися з думками, зосередитися, гасить емоції, усуває страхи, тривогу, стимулює творчу енергію, знімає стрес, м'язове напруження, заспокоює пульс і дихання, зменшує хвилювання. У великій кількості не варто застосовувати при зниженому тиску, може призвести до засмученості та плаксивості. Синій - знижує тиск, температуру, частоту серцевих скорочень і дихання, робочу активність, покращує мислення, має снодійний і знеболюючий ефект, заспокійливо діє на психіку, знімає спазми та головний 
біль, зменшує апетит, сприяє розвитку уваги й посилює інтелектуальну діяльність. У надлишку може призвести до емоційної сухості, депресії, викликати відчуття втоми. Фіолетовий - знімає напругу, неприємні відчуття в очах, допомагає знайти вихід із творчої кризи, зняти нервове перезбудження, покращує роботу серця, нирок, легень, підвищує тиск, нормалізує стан лімфатичної системи, допомагає при різних запальних захворюваннях, мігрені, сприяє підвищенню самооцінки, у творчих людей підвищує працездатність. У надмірній кількості сприяє появі відчуття втоми, депресії, надмірної мрійливості.

Коричневий - допомагає відчути себе захищеним, знімає тривогу, напругу, дарує спокій, сприяє прояву наполегливості та стабільності. У надмірній кількості викликає депресію, пригнічує фантазію, ініціативу й самостійність.

Сірий - колір стабільності, контролю емоцій (вказує на відсутність емоцій або їх пригнічення), а також пасивності й невпевненості. У надлишку заважає людині проявити себе, викликає депресію. Чорний- зміцнює та підвищує енергетичний потенціал людини, допомагає зосередитись. У великій кількості викликає депресію. Білий- надихає, дає силу, енергію, допомогає долати труднощі, вирівнює настрій, має лікувальну дію на ЦНС. У надлишку викликає відчуття розчарування, відчуженості та спустошеності.

Аналізуючи дію кольору на організм людини, ми дійшли висновку, що теплі кольори покращують фізіологічні процеси в організмі та м'язову працездатність, збуджують і піднімають настрій, а холодні - навпаки, уповільнюють фізіологічні процеси, заспокоюють і можуть пригнічувати психіку та викликати депресію.

у процесі добору кольорів слід пам'ятати про те, що вони безпосередньо діють через оточуюче середовище та не впливають на підсвідомість. Вплив кольору на організм людини залежить від таких показників: склад розуму; спосіб мислення; характер; тип темперамента (сангвінікам і холерикам підходять білий колір, сині та зелені відтінки, оскільки діють заспокійливо; а флегматикам і меланхолікам - червоні, помаранчеві та жовті кольори, оскільки діють збуджуюче).

Можна виділити такі методи застосування кольоротерапії в роботі з дітьми дошкільного віку: - малювання; - вживання їжі різного кольору; оздоблення кімнат; - предмети побуту та вжитку; - кольорові ванни; кольорова вода; - лампа з кольоровими фільтрами; - кольоропунктура.

Дошкільники досить рано починають відчувати колір і за допомогою нього передають свій настрій, емоції, ставлення до людей і оточуючого світу. Зазвичай діти під час малювання обирають до шести кольорів, якщо більше, то це свідчить про чуттєвість, емоційність дитячої натури, якщо ж обирають один або два кольори (синій - тривога, червоний - агресія, чорний депресія), то це вкузує на негативність стану в даний момент. Якщо ж дитина 
обирає простий олівець, це свідчить про відсутність або нестачу в ії житті яскравих фарб і гарних емоцій, тож дорослим слід про це замислитися. Найбільш значимі для дитини фігури вона розмальовує більшою кількістю кольорів, а тих, хто їй не дуже подобається, вона малює чорним або темнокоричневим кольором. Також колір у малюванні може передавати риси характеру та стан дитини залежно від кількості його використання в малюнку: темно-синій - концентрація на внутрішніх проблемах, потреба у спокої, зелений - прагнення до безпеки, рівновага; червоний - активність, підвищена збудливість, сила волі, агресія (якщо його забагато); жовтий цікавість, оптимізм, добрі емоції; фіолетовий - фантазія, емоційна та інтелектуальна зрілість; коричневий - фізичний дискомфорт, незручність, неприємні емоції; сірий - апатія, смуток, уникання тривожності; чорний пригніченість, протест, потреба у змінах (Скрипник, 2014, с. 20).

Малювати можна олівцями, фломастерами та фарбами за допомогою пензлика, ватної палочки, пальцями, долонею тощо. Якщо під час малювання дошкільники найчастіше обирають червоний, зелений, жовтий кольори - це свідчить про те, що дитина розвивається добре, ії цікавить усе нове, яскраве, незвичайне, а якщо обирає чорний і білий, це свідчить про їі замкнутість.

Уживання їжи різного кольору впливає на організм по-різному. Так, продукти червоного кольору (буряк, помідори, полуниця, малина, вишня тощо) покращують м'язовий тонус, кровообіг, стимулюють нервову систему, лікують депресію, зміцнюють імунітет, знімають утому, підвищують тиск, гемоглобін, очищають від токсинів. Продукти жовтого кольору (лимони, банани, жовток яйця, олія, жовті яблука та перець, кукуруза тощо) активізують мозок, сприяють розвитку творчих здібностей, збуджують апетит, очищують організм, зміцнюють стінки судин, позитивно впливають на роботу шлунково-кишкового тракту. Продукти помаранчевого кольору (абрикоси, хурма, лосось, апельсини, гарбуз, морква тощо) виводять токсини, допомагають при депресії, покращують зір, роботу шлунково-кишкового тракту, ендокринних залоз, дихальної системи. Продукти зеленого кольору (горох, капуста, огірки, кабачки, шпінат, авокадо, зелень тощо) позитивно впливають на роботу серця, легень, кишківника, знижують тиск, холестерин, заспокоюють нервову систему, знімають головний біль, утому очей. Продукти синього кольору (сливи, виноград, чорниця, ожина тощо) покращують концентрацію уваги, діють заспокійливо, знижують апетит, знімають спазми, покращують роботу щитоподібної залози, легень, очей. Продукти фіолетового кольору (баклажани, інжир, базілік, червонокочанна капуста, смородина тощо) знімають утому, покращують постачання кисню, стан шкіри, пам'ять, роботу головного мозку, нирок, жовчного та сечового міхура, зменшують біль у горлі, головний біль, запалення, очищують кров. Продукти коричневого кольору (шоколад, фініки, какао, кава, гречка, деякі 
сорта меду, печена картопля тощо) позитивно впливають на роботу очей, вух, носа, легень, щитоподібної залози, покращують настрій. Продукти білого кольору (молочні продукти, м'ясо курки, біла риба, рис, цукор, сіль, цибуля, часник тощо) діють заспокійливо, покращують роботу залоз внутрішньої секреції, зміцнюють кістки, запобігають застуді (Як впливають на організм людини продукти різного кольору?).

Велике значення в покращенні настрою дітей, створенні позитивного мікроклімату відіграє естетичне оформлення групової кімнати, ігрових куточків, роздягальні, спортивної та музичної зали, коридорів, території ЗДо; також позитивно на організм дітей впливає й милування природою; зосередженість зору на кімнатних рослинах; на певному кольорі протягом 10-15 хвилин. Так, у процесі вибору меблів і обладнання для дітей краще обирати світлі кольори натурального дерева або світло-зелені кольори, що підвищує їхню працездатність, дошка бажано, щоб теж була зеленого кольору, оскільки він не втомлює очі. Щоб зберегти спокій і позитивний психологічний мікроклімат, у групі необхідно оздоблювати предмети та стіни у спокійних, пастельних тонах. Зняттю нервового напруження в дітей і дорослих у закладах дошкільної освіти допомагають зелені, жовто-зелені та блакитно-зелені кольори; сині та блакитні - рекомендується застосовувати у фарбувані приміщень та обладнання, де дуже тепло (влітку жарко через південно-західне розташування вікон, а взимку гарне опалення) й галасливо; а червоні кольори можна застосовувати в приміщеннях, де діти знаходяться нетривалий час або там, де збудження необхідно (наприклад, у спортзалі, на ігровому або спортивному майданчику тощо) (Нестандартні методи психологічної допомоги: кольоротерапія).

Крім оформлення інтер'єру, також слід застосовувати відповідного кольору предмети побуту та вжитку: миски, чашки, серветки, рушники; іграшки; звертати увагу дітей на одяг різного кольору тощо. Так, посуд і предмети сервірування столу важливо використовувати визначеного кольору для покращення функцій травлення та нормалізації апетиту: блакитний, синій, бузковий, сіро-рожевий кольори знижують апетит; жовтогарячий - посилює. Також добираючи та зосерджуючи зір на одязі певного кольору, іграшках, предметах можна впливати на організм дітей.

Загальновідомо, що наша шкіра через воду сприймає найменьші коливання кожного кольору. Кольорові ванни можна отримати шляхом додавання у воду кольорової морської солі або підсвічуючи воду кольоровими лампами. Також можна використовувати колірний наповнювач для ванни. В умовах ЗДо можна застосовувати кольорові ванни для ніг.

Слід зазначити, що найкращими цілющими властивостями володіє кольорова вода, оскільки вода зберігає інформацію, а потім передає їі організму. Отримати таку воду можна двома способами. Перший спосіб: 
налити воду в ємність із кольорового скла (так, зелений - гармонізує та стабілізує, блакитний, синій або фіолетовий - заспокоює, жовтогарячий освіжає, червоний - дає заряд енергії та зігріває). Другий спосіб - взяти прозору склянку, налити в неї води та поставити на серветки різного кольору (із тканини, паперу чи картону) на 5-10 хвилин. Пити таку воду за півгодини до прийому їжі.

Лампи з кольоровими фільтрами або електричні лампочки різних кольорів можна використовувати в роботі з дітьми як для впливу на все тіло, так і на частину тіла чи орган. А на заняттях із фізичної культури за допомогою кольорових ламп можна впливати на фізіологічний стан дитини: для приведення частоти дихання та серцевих скорочень у відносно спокійний стан застосовують лампи блакитного кольору, для підвищення рухової активності, моторної діяльності - жовтогарячі, червоні. Міняючи колір фільтрів або різнокольорові лампочки в патроні люстри можна отримати різні ефекти: блакитний, синій, зелений - заспокійливі, жовтий зігріваючий, червоний - активізуючий, рожевий - розслаблюючий. Також можна використовувати запалену свічку, яку поміщаємо в склянки різного кольору (Изотова, Сарафанова, Мицьо, Ионова, 2007, с. 199).

Кольоропунктура - вплив забарвлених променів на меридіани тіла, на точки акупунктури людського тіла. Також можна на шкіру накладати кольорову плівку та направляти на неї промінь ліхтарика (Izotova, Sarafanova, Mithyo, Ionova, 2007, с. 199; Skrypnyk, 2014, с. 28). Застосовують при болях у кістках і суглобах, опіках, шкіряних захворюваннях, головних болях, мігрені.

у психодіагностиці з метою визначення в досліджуваного функціонального та емоційного стану, найбільш стійких рис особистості використовують тест М. Люшера. Для визначення в дітей настрою, емоційного та психічного стану можна проводити різні діагностичні, графічні та реабілітаційні вправи.

\section{Діагностична вправа «Квітка-семибарвка»}

Mema: визначення емоційного стану дитини відповідно до кольорової гами: жовтий - радість; червоний - щастя; синій - образа; зелений - спокій; сірий - сум; помаранчевий - здивування; коричневий - втома.

Обладнання: кольорові картки у формі пелюсток квітки, розкладені в довільному порядку.

Завдання. Взяти в руки пелюстку того кольору, який вам сьогодні найбільше до вподоби, з яким хочеться потоваришувати, побути довше (Нестандартні методи психологічної допомоги: кольоротерапія).

Графічна вправа «Хвилинка-кольоринка»

Mema:діагностування емоційного стану дитини, розширення емоційної сфери; емоційний відпочинок дитини.

обладнання: кольорові олівці, фломастери, папір. 
Завдання: намалюйте те, що побажаєте (просто лінії, кульки, сніжинки, квіти тощо), використовуючи кольорові олівці або фломастери.

Час на виконання вправи: 4-5 хв. (Нестандартні методи психологічної допомоги: кольоротерапія).

\section{Реабіталіційна вправа «Зоряне дихання»}

Mema: протидія болю будь-якого походження, тривозі, страху, поганому настрою.

Завдання: педагог пропонує дітям виконувати його вказівки: сісти зручніше, а краще - приляти. Уявити небо, засіяне зорями. Оберіть одну зірочку. Виберіть колір і засвітіть зірочку цим кольором. Кольоровий промінь широкий, він усе довкола заповнює своїм сяйвом. Вдихніть (порахувавши до трьох), уявляючи, що ви вдихаєте кольорове повітря. Повітря, проникає через ніс і заповнює усе ваше тіло. Спробуйте побачити та відчути це. Вдихайте носом. Затримайте дихання, порахувавши до трьох. Видихніть (порахувавши до трьох). Повторити 3 рази (Скрипник, 2014, с. 32).

Висновки та перспективи подальших наукових розвідок. Отже, колір оточує дитину та безпосередньо через оточення здійснює на ї організм психофізіологічний вплив. Застосування кольоротерапії шляхом поєднання різних її методів у роботі з дітьми дошкільного віку позитивно впливає на їх настрій, самопочуття, комунікабельність, роботу внутрішніх органів і систем організму, активізує рухову активність, роботу мозку, розвиває психічні процеси, тобто сприяє збереженню та зміцненню фізичного, психічного, духовного й соціального здоров'я. Перспективою подальших розвідок ми вбачаємо в дослідженні особливостей застосування кольоротерапії з дітьми дошкільного віку в дидактичних іграх і в арт-терапії.

\section{ЛITЕРАТУРА}

Герасименко, К. В. (2014). Кольоротерапія як засіб корекції різних форм порушення. Вісник Кам'янець-Подільського національного університету ім. І. Огієнка. Корекційна педагогіка і психологія, 5, 20-28. (Gerasimenko, K. V. (2014). Color therapy as a means of correction of various forms of disorders. Kamyanets-Podilsky National University. I. Ogienko Bulletin, 5, 20-28).

Гёте, И. В. (2012). Учение о цвете. Теория познания. М.: Либроком. (Goethe J. W. (2012). The doctrine of color. Knowledge theory. $\mathrm{M}$.: Librockom).

Денисенко, Н. (2006). Колір у нашому житті. Дошкільне виховання, 11, 16-19. (Denysenko, N. (2006). Color in our lives. Preschool education, 11, 16-19).

Изотова, М. А., Сарафанова, Н. А., Мицьо, В. П., Ионова, А. А. (2007). Большая энциклопедия народной медицины. М.: олМА Медиа Групп (Izotova, M.A., Sarafanova, N. A., M ithyo, V. P., Ionova, A. A. (2007). The Big Encyclopedia of Folk Medicine. M.: OLM A M edia Group.

Єфименко, М. (1998). Колір у фізичному вихованні дошкільнят. Дошкільне виховання, 11-12, 18-19. (Yefimenko, M. (1998). Color in physical education of preschool children. Preschool education, 11-12, 18-19.

Киселёва, М. В. (2006). Арт-терапия в работе с детьми. СПб.: Речь. (Kiseleva, М. V. (2006). Art therapy in work with children. St. Petersburg.: Speech). 
Кольоротерапія. Лікування мистецтвом (2014). І. М. Скрипник (укладач). Рівне. (Color therapy. Treatment with art (2014). I. M. Skrypnyk (Compiled by). Rivne.

Нестандартні методи психологічної допомоги: кольоротерапія. Режим доступу: http://ru.osvita.ua/school/lessons summary/psychology/38702/ (Non-standard methods of psychological help: color therapy. Retrieved from: http://ru.osvita.ua/school/lessons summary/psychology/38702/).

Як впливають на організм людини продукти різного кольору? Режим доступу: https://www .epochtimes.com.ua/health/traditions/produkty-riznogo-koloru-

72745.html (How do products of different colors affect the human body?) Retrieved from: https://www.epochtimes.com.ua/health/traditions/produkty-riznogo-koloru72745.html

\section{РЕЗЮМЕ}

Лисневская Наталия. Особенности использования цветотерапии с детьми дошкольного возраста как средство влияния на их здоровье.

В статье подаётся исторический очерк исследований прошлого и настоящего относительно влияния цвета на организм человека с лечебной челью. Раскрывается значение цветотерапии как нетрадиционного средства сохранения и укрепления здоровья детей дошкольного возраста. Даётся характеристика каждого ивета с точки зрения влияния его на организм человека. Называются методы использования иветотерапии в работе с детьми дошкольного возраста в дошкольных образовательных учреждениях и описываются пути их реализации. Подаются примеры диагностических, графических и реабилитачионных упражнений. Определяется влияние цветотерапии на сохранение здоровья детейдошкольников и перспективы последующих исследований особенностей использования цветотерапии в дидактических играх и в арт-терапии.

Ключевые слова: ивет, цветотерапия, оздоровительные технологии, нетрадиционны средства оздоровления, цветная вода, цветные ванны, диагностическое упражнение, реабилитационное упражнение.

\section{SUMMARY}

Lisnevska Natalia Features of color therapy application in working with preschool children as a means of the influence on their health.

The article emphasizes that health is a value that must be preserved and strengthened from birth and taught to preschool children. Traditional health remedies are said to be the most effective, but the importance of using non-traditional remedies is also noted - wellness technologies, which include color therapy. It is emphasized that influence of color on the human body has been studied for a long time. An analysis is made of the scientific works of philosophers, physicians, scientists on the effects of color on the body and the health of man and child. The importance of color therapy for the health of preschool children and the effect of a certain color on the human body are revealed. M ethods of using color therapy to preserve and promote the health of preschool children are identified, and their detailed description is provided. Prescribes the peculiarities of the use of colors by children of preschool age in drawing in order to diagnose their character traits and mental state. Examples of food products of different colors are given and their effects on the human body are revealed. The role of aesthetic design of a group room, play areas, dressing room, sports and music hall, corridors, PEl territory in improving the mood of children, creating a positive microclimate is analyzed. The influence of the color of everyday objects, consumption and clothing on the organism of children is revealed and the ways of their use 
in the educational process of the institution of preschool education are characterized. It is emphasized that colored baths for feet can be used in the conditions of the PEl. The description of the methods of obtaining colored water in the PEl is given. The ways of using colored filters or light bulbs of different colors when working with children are described. The features of color puncture with preschool children and its impact on the human body are highlighted. Examples of diagnostic, graphic and rehabilitation exercises are given to diagnose emotional and mental state of children, improve mood and well-being, remove anxiety and stress. It is stated that color through the environment has a psychophysiological influence on the organism of children and the prospects for further studies of the features of the use of color therapy in didactic games and art therapy are determined.

Key words color, color therapy, wellness technologies, non-traditional means of healing, colored water, colored baths, diagnostic exercise, rehabilitation exercise.

удк 37.013.42:077.5-042.72]-053.67:791](045)

Нанулі Потьомкіна

Харківська державна академія культури

ORCID ID0000-0002-4269-3824

DOI 10.24139/2312-5993/2020.01/082-094

\section{СОЦІАЛЬНО-ПЕДАГОГІЧНА ПРОФІЛАКТИКА ЗАЛЕЖНОСТІ СТАРШОКЛАСНИКІВ ВІД СОЦІАЛЬНИХ МЕРЕЖ ЗАСОБАМИ КІнОПРОДУКції}

У статті проаналізовано й узагальнено особливості соціального розвитку старшокласників в умовах інформачійного суспільства. Відзначено, що актуальні сочіальні потреби старшокласників (спілкування, самопрезентація, кохання, дружба, визнання, популярність та ін.) знаходять свою реалізацію саме в кіберстосунках у сочіальних мережах, які, на додачу, технологічно побудовані таким чином, аби максимально заволодіти увагою й часом молоді, що, зрештою, призводить до нав'язливого потягу й залежності. Виходячи з основ сочіальновиховної парадигми пропонується розробка технологій сочіально-педагогічної профрілактики залежності старшокласників від сочіальних мереж, використовуючи обговорення й аналіз кінопродукції ігрового кіно.

Ключові слова: старшокласники; кіберпростір; кібер-залежність; залежність старшокласників від соціальних мереж; сочіально-педагогічна профрілактика; кінопродукція як засіб соціально-педагогічної профрілактики.

Постановка проблеми. В епоху інформатизації, у XXI столітті, інформація стала головною цінністю; відбувається формування й затвердження «інформаційної свідомості»; традиційні соціальні конфлікти перемістилися з реального матеріального простору в принципово новий кіберпростір або віртуальний простір, у якому шахрайсько-маніпулятивні технології набувають більш широкого застосування; розвиваються нові інформаційно-комунікаційні технології (IKT) та засоби масової комунікації (ЗМК). Завдяки останнім здійснюється вплив на масову свідомість, ведуться інформаційні мережеві протистояння й кібервійни, знищуються окремі 